\title{
PLANT DIVERSITY AND COMMUNITY ATTRIBUTES OF WOODY PLANTS IN TWO CLIMAX SUBTROPICAL HUMID FORESTS OF MEGHALAYA, NORTHEAST INDIA
}

\author{
MISHRA, B.P. ${ }^{1,2}-$ JEEVA, S. ${ }^{1,3 *}$ \\ ${ }^{1}$ Ecology Laboratory, Centre for Advanced Studies in Botany, School of Life Sciences, North- \\ Eastern Hill University, Umshing - Mawkynroh, Shillong - 793 022, Meghalaya, India \\ ${ }^{2}$ Department of Environmental Science, Mizoram University, Post Box-190, Aizawl- 796001 , \\ Mizoram, India \\ ${ }^{3}$ Department of Botany, Scott Christian College (Autonomous), Nagercoil - 629 003, Kanyakumari, \\ Tamil Nadu, India \\ (phone: + 91-364-2722227) \\ *Corresponding author \\ e-mail: solomonjeeva@gmail.com \\ (Received $5^{\text {th }}$ September 2008; accepted $5^{\text {th }}$ January 2012)
}

\begin{abstract}
The present study was conducted in two sacred forests, representing subtropical humid forest of the state of Meghalaya, India. Measurement of canopy cover, light interception and disturbance index revealed that these two sacred forests are comparable with respect to plant diversity and community attributes. The disturbance index was slightly higher in Mairang sacred forests, which had supported high species richness, better recruitment of seedlings leading to high regeneration potential. This was due to formation of gaps within forest. On other hand, gaps facilitated expansion of crown of trees, which inhibited growth and survival of saplings, the retarded growth of saplings had resulted in low conversion of saplings to trees. This condition could also be a reason for high basal area and low tree density in Mairang sacred forest. Endemic, rare and rare endemics were also reported from both the forests. Altitude had impacted composition, and dominance of species and families. Both the forests were highly dissimilar with respect to species composition. Contagious distribution was prevalent in both the forests, clumping is a characteristic feature of natural forest in tropical and subtropical region. Wide-girth structure and log-normal dominance-distribution curves justify complexity and stability of communities that lead to climax vegetation.
\end{abstract}

Keywords: Population attributes, regeneration potential, sacred forest, subtropical humid forest, woody species diversity

\section{Introduction}

Biodiversity refers to the quality, range or extent of variation between the biological entities in a given set. Plant community dynamics and vegetation management is intricately interrelated, and an understanding of the basic processes involved in vegetation change is essential for the sound manipulation of plant communities (Niering, 1987). Larger environmental variation within a small geographical area makes altitudinal gradients ideal also for several ecological and biogeographical hypotheses (Wilson et al., 1990; Korner, 2000; Ohlemuller \& Wilson, 2000), therefore, altitudinal gradient has become increasingly popular for investigating patterns in species richness (Rohde, 1992; Rahbek, 1995; Odland \& Birks, 1999; Kessler, 2000; Srinivas \& Parthasarathy, 2000; Grytnes, 2003).

APPLIED ECOLOGY AND ENVIRONMENTAL RESEARCH 10(4): 417-436. http://www.ecology.uni-corvinus.hu • ISSN 15891623 (Print) • ISSN 17850037 (Online) (c) 2012, ALÖKI Kft., Budapest, Hungary 
In India, northeast region is an extension of eastern Himalaya. It has stable geological history, equable climate, heavy and uniform rainfall, which support a wide range of subtropical forest ecosystem (Champion \& Seth, 1968) and considered as hot spot of plant diversity (Myers, 1988; Groombridge, 1992; Myers et al., 2000; Behera et al., 2002). Phytogeographically, forests of this region are species rich, and harbor a number of phylogenetically primitive plant species and regarded as a "treasure trove" of ancient and unique vegetation (Champion \& Seth, 1968). Takhtajan (1969) has considered these forests as the cradle of flowering plants.

As per an estimate of Forest Survey of India (1997), the actual forest cover in Meghalaya is about $41.6 \%\left(9330 \mathrm{~km}^{2}\right)$ of the total geographical area $\left(22429 \mathrm{~km}^{2}\right)$ of the state. The subtropical semi-evergreen forests topped the list with coverage of $21.4 \%$ land and is followed by subtropical semi-evergreen forest (11.9\%), subtropical pine forest (7.6 $\%$ ) and sal forest $0.1 \%$ (Mishra et al., 2005a). That the subtropical humid forests are found in tropical and subtropical belts, and inhabit major population of plant species, act as reservoirs of biodiversity (Whitmore, 1984; Whitmore \& Sidiyasa, 1986; WCMC, 1992; Richards, 1996; Whitmore, 1998; Fashing \& Gathua, 2004; Fashing et al., 2004).

The sacred forests of Meghalaya are the best example of subtropical humid forests. Indigenous people of Meghalaya protect some forest patches traditionally since time immemorial due to strong religious beliefs anointed with groves (sacred forests), such tracts of forests are species rich and regarded as virgin forests, and are popularly known as sacred forests or sacred groves (Gadgil \& Vartak, 1975, 1976). The forefathers of indigenous people made a simple way for conservation of sacred forests by attaching various orthodox religious laws, myths and taboos attached with them. Over the years, these forests have become a part of the cultural life of the indigenous people of the Meghalaya. These forests often act as a gene bank, as they are rich in genetic resources (UNEP, 1995; Mc.Neely, 1996; Edwards \& Cyrus, 1998). Moreover, these forests are considered as a repository of plant diversity and refugia for rarity and endemism (Jeeva \& Anusuya, 2005; Jeeva et al., 2005, 2006a; Mishra et al., 2005b, 2005c). Previously, the sacred forests were found near each and every village. Ongoing struggle between a popular belief and need of people has resulted in extinction of several sacred forests, many are on verge of extinction, some are facing different degrees of disturbance and few forests are still protected and they harbor climax vegetation.

Change in landscape due to human interference has been identified as the major threat to biodiversity in terms of loss of species and change in community structure (Daniels et al., 1991; Daniels et al., 1995; Gadgil, 1996; Daniels, 1997; Menon \& Bawa, 1997; Pramod et al., 1997; Nagendra \& Gadgil, 1998; Nagendra \& Gadgil, 1999a, 1999b; Nagendra, 2001; Nagendra \& Utkarsh, 2003). Oldfield and his coworkers (1998) have reported 10\% of the world's tree species under threat. Anthropogenic disturbance causes maximum loss to trees layer than other plant groups such as shrubs, climbers and herbs. Thus, conservation of plant resources has become a global issue owing to habitat destruction, deforestation, climate change and environmental degradation (Phillips, 1997; Myking, 2002).

The conservation and forest management operation requires quantitative information of biodiversity inventories such as species diversity, population structure, and distribution pattern of species and other community attributes (Andel, 2001; Singh, 2002). Such biodiversity inventories are best integrated with the timber resources in order that forest 
management operations can be planned (Rennolls \& Laumonier, 2000). Being a dominant life form, trees are easy to locate precisely and to count (Condit et al., 1996) and are also relatively better known, taxonomically (Gentry, 1992; Sagar et al., 2003). Quantification of tree species diversity is an important aspect as it provides resources and habitat for many species (Cannon et al., 1998).

In the state of Meghalaya hilly terrain and undulating topography have resulted in marked variation in altitude, irrespective of distance. The similar kind of forests situated in nearby area having differed altitude, the species composition varied greatly. The ecologists have paid little attention on researches to gather information, that how altitudinal variation affects species composition, plant diversity, community attributes and population structure in similar kinds of forests. Pooling the data from such kind of studies could be an effective tool for development of appropriate measures for rehabilitation of degraded forests land using plant species regenerating efficiently in respective edapho-climatic conditions.

In view of the above, the present study was carried out to determine extent of change in species composition, plant diversity, community attributes and population structure in Mairang and Mawphlang sacred forests of Meghalaya, representing of subtropical humid forest.

\section{Materials and methods}

\section{Study area}

The present study was conducted in two sacred forests of Meghalaya namely, Mawphlang and Mairang sacred forests, representing subtropical humid forests. (Fig.1). The Mawphlang sacred forest $\left(25^{\circ} 34^{\prime} \mathrm{N}, 91^{0} 56 \mathrm{E}\right.$, altitude $1430 \mathrm{~m}$ asl) is located about 28 $\mathrm{km}$ southwest of Shillong in the East Khasi Hills district of Meghalaya. It occupies an area of about 75 hectare and is surrounded by a landscape covering grassland vegetation. Another study site, the Mairang sacred forest $\left(125^{\circ} 33^{\prime} \mathrm{N}, 91^{0} 38^{\prime} \mathrm{E}, 1748 \mathrm{~m}\right.$ asl $)$ is situated near Mawnai village at Mairang town in the West Khasi Hills district of Meghalaya and it has an area of about 80 ha. The distance between the two forests is about $30 \mathrm{~km}$, but they are situated at an altitudinal variation of about $300 \mathrm{~m}$ asl.

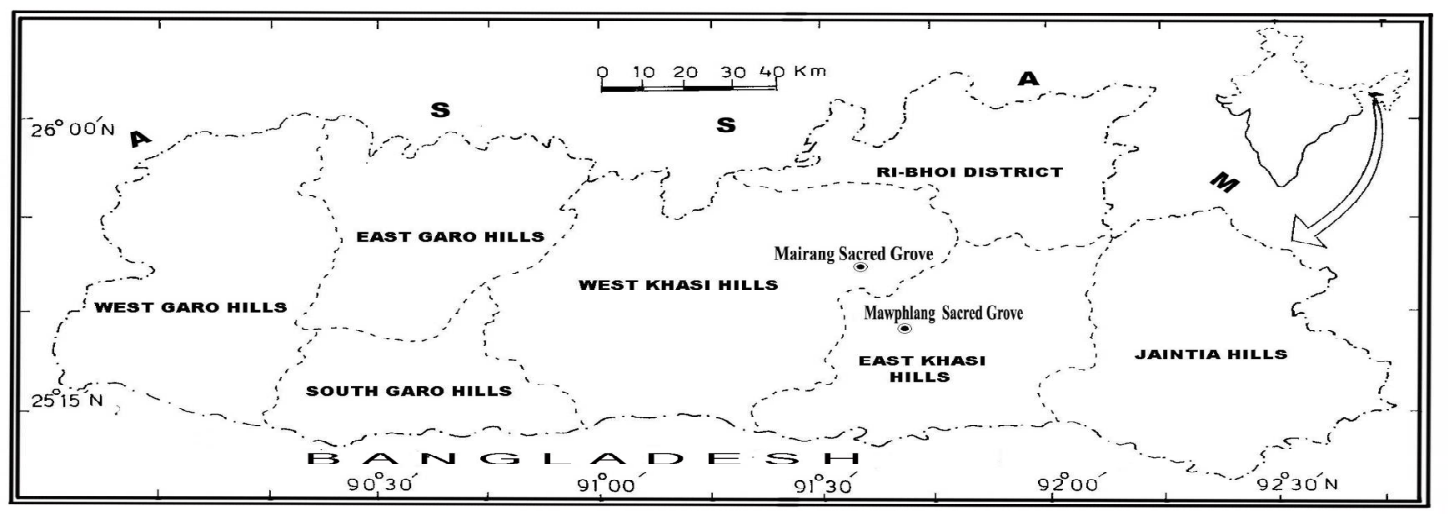

Figure 1. Geographical location of study area

APPLIED ECOLOGY AND ENVIRONMENTAL RESEARCH 10(4): 417-436. http://www.ecology.uni-corvinus.hu • ISSN 15891623 (Print) • ISSN 17850037 (Online) (c) 2012, ALÖKI Kft., Budapest, Hungary 


\section{Vegetation profile}

The vegetation of both sacred forests falls under semi-evergreen subtropical broadleaved wet-hill forests (Champion \& Seth, 1968). The canopy tree species are Aporusa dioica, Castanopsis kurzii, Camellia caduca, Corylopsis himalayana, Engelhardtia spicata, Exbucklandia populnea, Ficus nerifolia, Garcinia cowa, Ficus nerifolia, Myrica esculenta, Pyrus pashia, Quercus griffithi, Quercus dealbata, Quercus glauca, Rhododendron arboreum and Taxus baccata in Mawphlang sacred forest. However, canopy layer of Mairang sacred forest is composed of Aesculus assamica, Aporusa roxburghii, Beilschmiedia brandisii, Beilschmiedia roxburghiana, Citrus medica, Cleidion javanicum, Cryptocarya amygdalina, Cryptocarya andersonii, Dysoxylum binecteriferum, Echinocarpus assamicus, Echinocarpus dasycarpus, Echinocarpus murex, Fissistigma wallichii, Macropanax undulatus, Ostodes paniculata, Phoebe sp., Quercus griffithii, Quercus smiserrata, Rhus acuminata, Sapium baccatum Schima wallichii and Trevesia palmata. The tree species composition suggests that these forests are semi-evergreen types (NRSA, 1995; FSI, 1997). The canopy cover, light interception, and disturbance index justify that there is no marked variation in status of two sacred forests, in terms of disturbance. The disturbance index was very low and it was slightly higher in the Mairang sacred forest than Mawphlang sacred forest. The value of disturbance index depicts that both the forests are undisturbed/mildly disturbed (Table 1).

Table 1. Canopy cover, light interception and disturbance index in the two sacred forests of Meghalaya

\begin{tabular}{c|c|c}
\hline Parameters & \multicolumn{2}{|c}{ Sacred forests } \\
& Mairang & Mawphlang \\
\hline Canopy cover (\%) & $50-100$ & $60-100$ \\
Light interception (\%) & $40-100$ & $50-100$ \\
Disturbance index (\%) & $0-3$ & $0-1$ \\
\hline
\end{tabular}

\section{Climate and soil}

The monsoon season is characteristics of the climate of Meghalaya. The state receives rainfall throughout the year and about $85 \%$ of the annual rainfall is received during the wet season (June to September). The mean annual rainfall is accounted as $2500 \mathrm{~mm}$ (Jeeva et al., 2006b). The soil is mainly lateritic and derived from gneisses, schists and granites of Archean age (Gansser, 1964).

\section{Methodology}

The field study was conducted during 2000-2001 following the methods as outlined by Misra (1968), Kershaw (1973), Muller-Dombois and Ellenberg (1974). The vegetation analysis was done by quadrat method. In each forest, 50 quadrats were laid randomly for trees $(\mathrm{gbh}>20 \mathrm{~cm}$ ) and shrubs ( $\mathrm{gbh} 5 \mathrm{~cm}$ to $20 \mathrm{~cm}$ and/or individuals more than $1 \mathrm{~m}$ height), using quadrats of size $10 \mathrm{~m} \times 10 \mathrm{~m}$ and $5 \mathrm{~m} \times 5 \mathrm{~m}$, respectively. For seedlings ( $\mathrm{gbh}<5 \mathrm{~cm}$ and/or individuals up to $1 \mathrm{~m}$ height), 100 quadrats $(1 \mathrm{~m} \times 1 \mathrm{~m}$ size) were laid in each forest. The density, frequency, basal area and importance value index (IVI) were computed. The 
distribution pattern of species was determined by computing Whitford index (Whitford, 1948). The dominance-distribution pattern was determined at both the species and family levels. The disturbance index was calculated by using the formula used by Mishra et al. (2003). The species richness index (Margalef, 1958), Shannon diversity index (Shannon and Weaver, 1949) and Simpson dominance index (Simpson, 1949) were determined.

Species richness index (Margalef, 1958) $=\mathrm{S}-1 / \ln \mathrm{N}$

where, $\mathrm{S}$ is the total number of species, $\mathrm{N}$ is total number of individuals and $\ln$ is $\log 2$.

Diversity index (Shannon and Weaver, 1949)

$$
H^{\prime}=-\sum_{i=1}^{s} p i \ln p i
$$

where, $H^{\prime}$ is the Shannon-Weiner diversity index, pi is the proportion of IVI of a species i.e. $(n i / N)$.

Dominance index (Simpson, 1949)

$$
\mathrm{Cd}=\sum_{i=1}^{s}(p i)^{2}
$$

Disturbance index $(\%)=\frac{\text { Number of tree stumps }}{\text { Total number of trees including tree stumps } \times 100}$

Plants species were identified using regional floras (Balakrishnan, 1981-83, Haridasan and Rao, 1985-87, Kanjilal et al., 1934-40). Plant specimens were counter-checked with the reference material available at the Botanical Survey of India, Eastern Circle Shillong and herbarium of the Department of Botany, North-Eastern Hill University, Shillong. The Red Data Book (Nayar \& Sastry, 1987, 1988, 1990) and Balakrishnan \& Vasudeva (1983) were consulted to ascertain rarity and endemicity.

\section{Results}

\section{Species composition, distribution pattern and similarity}

Altogether, 186 woody species belonging to 124 genera and 59 families of angiosperms were recorded from one ha area of two forests (i.e., 0.5 ha area of each forest). Result showed that contagious distribution was predominant in both the forests. Of 133 species in Mairang sacred forest, 132 species showed contagious and one species namely Citrus medica was distributed randomly. On other hand, 62 species showed contagious, 9 species random and 10 species regular distribution in Mawphlang sacred forest. The Sprensen 
index of similarity between two forests was calculated very low (27\%), only 29 species were common in both the forests (Appendix 1).

\section{Endemicity and rarity}

From both the forests, 11 endemic, 7 rare and 5 rare as well as endemic species were recorded. The rare endemics were Baliospermum micranthum, Cinnamomum pauciflorum, Ilex embelioides, Ilex khasiana and Lindera latifolia. Among rare species, Anomospermum excelsum, Antidesma roxburghii, Baliospermum micranthum, Beilshmiedia fagifolia, Cinnamomum pauciflorum, Cordia fragrantissima, Fagraea ceilanica, Helicia excelsa and Psychotria symplocifolia and Camellia caduca were noticed. The endemic species were Carpinus viminca, Daphniphyllum himalayense, Elaeocarpus acuminatus, Erythroxylum kunthianum, Michelia punduana, Neillia thyrsiflora, Persea kingii, Quercus glauca, Schima khasiana and Zanthoxylum khasianum (Appendix 1).

\section{Floristic richness, diversity and dominance}

Woody species content was markedly high in Mairang sacred forest (133 species) than Mawphlang sacred forest (81 species). A similar trend of result was also obtained with respect to generic composition, a total of 92 genera in former and 65 genera in later case were recorded. Similarly, family richness was also higher in Mairang sacred forest (48 families) than Mawphlang (40 families) sacred forest. The number of species per $100 \mathrm{~m}^{2}$ was reported very high in Mairang sacred forest (26) than Mawphlang sacred forest (12). Species richness index and Shannon diversity index were high in Mairang sacred forest. The Simpson dominance index was contrary to the diversity index. Both the forests had high diversity and low dominance indices (Table 2).

Table 2. Plant diversity and other community attributes in the two sacred forests of Meghalaya

\begin{tabular}{l|c|c}
\hline \multicolumn{1}{c|}{ Parameters } & $\begin{array}{c}\text { Mairang } \\
\text { sacred forest }\end{array}$ & $\begin{array}{c}\text { Sacred forests } \\
\text { Mawphlang } \\
\text { Sacred forest }\end{array}$ \\
\hline Number of families & 48 & 40 \\
Number of genera & 92 & 65 \\
Number of species & 133 & 81 \\
Species richness (species per $100 \mathrm{~m}^{2}$ ) & $26 \pm 1.5$ & $12 \pm 1.2$ \\
Tree density (individuals ha ${ }^{-1}$ ) & $1256 \pm 64$ & $1490 \pm 59$ \\
Sapling density (individuals ha ${ }^{-1}$ ) & $5690 \pm 114$ & $4230 \pm 80$ \\
Seedling density (individuals ha ${ }^{-1}$ ) & $41700 \pm 417$ & $37900 \pm 379$ \\
Tree basal area (m ${ }^{2}$ ha ${ }^{-1}$ ) & $42.8 \pm 3.9$ & $21.7 \pm 2.3$ \\
Margalef species richness index & 18.5 & 12.4 \\
Shannon diversity index & 4.5 & 3.9 \\
Simpson dominance index & 0.014 & 0.01 \\
\hline
\end{tabular}

APPLIED ECOLOGY AND ENVIRONMENTAL RESEARCH 10(4): 417-436. http://www.ecology.uni-corvinus.hu • ISSN 15891623 (Print) • ISSN 17850037 (Online) (c) 2012, ALÖKI Kft., Budapest, Hungary 
In the Mairang sacred forest, Citrus medica was the dominant (IVI 14. 3) species, however, Rhododendron arboreum was the dominant (IVI 39. 65) species in Mawphlang sacred forest. Alangium chinense (IVI 0.25) and Ardisia undulata (IVI 0.24) were least dominant species in Mairang and Mawphlang sacred forests, respectively. The distribution of IVI among species was more uniform among the species in Mairang sacred forest (Appendix 1). The dominance-distribution curve followed a log-normal distribution pattern in both the forests, with short curve in Mawphlang sacred forest (Fig. 2).

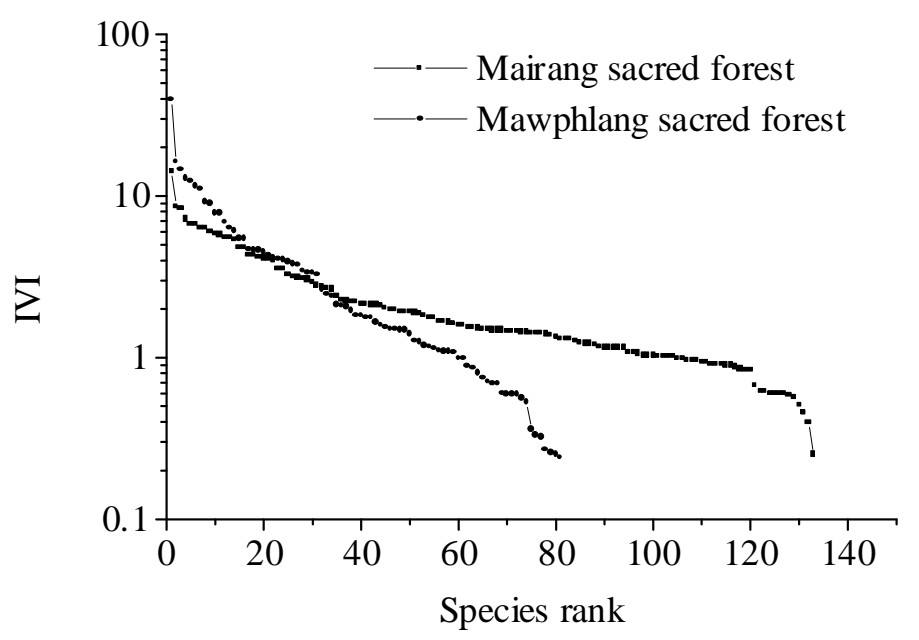

Figure 2. Dominance-distribution pattern of species in two sacred forests of Meghalaya

\section{Density and tree basal area}

Result showed that seedling recruitment was markedly high in both the forests, seedling density was high in Mairang sacred forest (41700 individuals ha ${ }^{-1}$ ) than Mawphlang sacred forest (37900 individuals $\mathrm{ha}^{-1}$ ). Sapling density also followed a similar trend. On the contrary, Mawphlang sacred forest had more tree density (1490 individuals ha $\left.^{-1}\right)$ than Mairang sacred forest (1256 individuals $\mathrm{ha}^{-1}$ ). Irrespective of tree density, the basal area was about two folds higher in Mairang sacred forest $\left(42.8 \pm 3.9 \mathrm{~m}^{2} \mathrm{ha}^{-1}\right)$ than the Mawphlang sacred forest $\left(21.7 \pm 2.3 \mathrm{~m}^{2} \mathrm{ha}^{-1}\right)$ (Table 2).

Girth class distribution of individuals declined sharply from lower to higher girth classes in both the forests and it showed a pyramidal structure. Both the forests had a wide-range girth structure. The Mawphlang sacred forest was represented by individuals up to girth class $250-300 \mathrm{~cm}$. However, Mairang sacred forest had a few individuals having girth more than $300 \mathrm{~cm}$. Adults $(\mathrm{gbh} 20-50 \mathrm{~cm})$ were predominantly present in both the forests, i.e., $62 \%$ and $80 \%$ in Mairang and Mawphlang sacred forests, respectively (Fig. 3). 


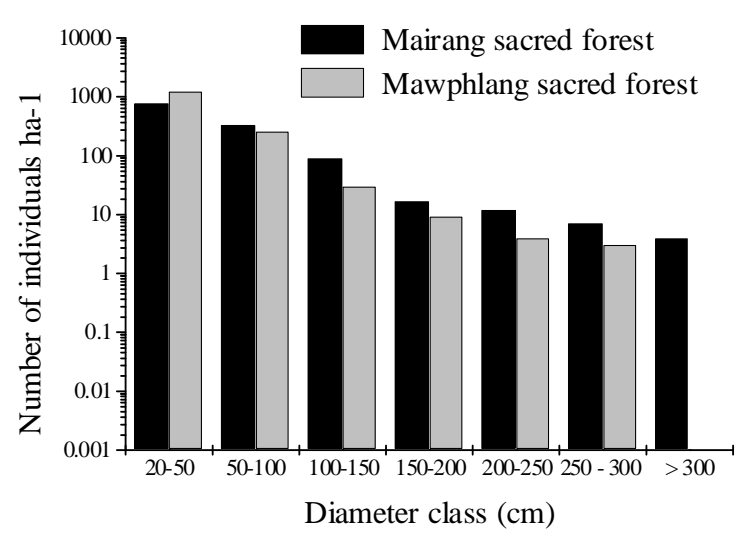

Figure 3. Girth-distribution of trees $(\mathrm{gbh}>20 \mathrm{~cm})$ in the Mairang and Mawphlang sacred forests Girth-distribution

\section{Distribution and dominance of families of angiosperms}

Altogether, 59 families of angiosperms were reported from both the forests. The Mairang sacred forest was represented by 48 families, however, 40 families were recorded from Mawphlang sacred forest. In Mairang sacred forests, Lauraceae (17 species) was the dominant family. Euphorbiaceae, the codominant family was represented by 11 species. Euphorbiaceae and Lauraceae with 12 and 10 species respectively, were dominant and codominant families in the Mawphlang sacred forest. The number of families represented by a single species was higher in Mawphlang sacred forest (26) than Mairang sacred forest (23). Generic composition had depicted that Euphorbiaceae dominating in both the forests as it had highest number of genera (Table 3). Dominance distribution of families has resulted in log-normal distribution of families in both the forests (Fig. 4).

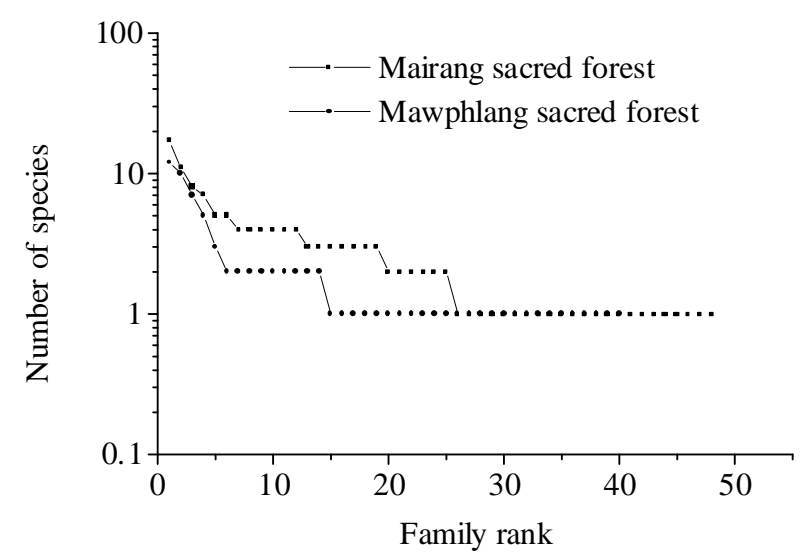

Figure 4. Dominance-distribution pattern of families in two sacred forests of Meghalaya

APPLIED ECOLOGY AND ENVIRONMENTAL RESEARCH 10(4): 417-436. http://www.ecology.uni-corvinus.hu • ISSN 15891623 (Print) • ISSN 17850037 (Online) (c) 2012, ALÖKI Kft., Budapest, Hungary 
Mishra - Jeeva: Plant diversity and community attributes of woody plants in two climax subtropical humid forests of Meghalaya $-425-$

Table 3. Genera and species composition of different families of angiosperms recorded from the two sacred forests of Meghalaya. The families are arranged with respect to family rank based on number of species in a particular family

\begin{tabular}{|c|c|c|c|c|c|c|}
\hline \multirow{2}{*}{$\begin{array}{c}\text { Family } \\
\text { Rank }\end{array}$} & \multirow[t]{2}{*}{ Family } & \multicolumn{2}{|c|}{$\begin{array}{l}\text { Mairang sacred } \\
\text { forest }\end{array}$} & \multirow[t]{2}{*}{ Family } & \multicolumn{2}{|c|}{ Mawphlang sacred forest } \\
\hline & & Genera & Species & & Genera & Species \\
\hline 1 & Lauraceae & 7 & 17 & Euphorbiaceae & 10 & 12 \\
\hline 2 & Euphorbiaceae & 9 & 11 & Lauraceae & 7 & 10 \\
\hline 3 & Araliaceae & 6 & 8 & Fagaceae & 2 & 7 \\
\hline 4 & Rubiaceae & 7 & 7 & Theaceae & 4 & 5 \\
\hline 5 & Elaeocarpaceae & 2 & 5 & Lamiaceae & 3 & 3 \\
\hline 6 & Theaceae & 3 & 5 & Clusiaceae & 1 & 2 \\
\hline 7 & Anacardiaceae & 2 & 4 & Elaeocarpaceae & 2 & 2 \\
\hline 8 & Verbenaceae & 3 & 4 & Ericaceae & 2 & 2 \\
\hline 9 & Symplocaceae & 1 & 4 & Hamamelidaceae & 2 & 2 \\
\hline 10 & Magnoliaceae & 1 & 4 & Magnoliaceae & 1 & 2 \\
\hline 11 & Oleaceae & 2 & 4 & Moraceae & 1 & 2 \\
\hline 12 & Rosaceae & 4 & 4 & Myricaceae & 1 & 2 \\
\hline 13 & Rutaceae & 3 & 3 & Proteaceae & 1 & 2 \\
\hline 14 & Annonaceae & 3 & 3 & Rosaceae & 2 & 2 \\
\hline 15 & Fagaceae & 1 & 3 & Actinidiaceae & 1 & 1 \\
\hline 16 & Buxaceae & 1 & 3 & Apocynaceae & 1 & 1 \\
\hline 17 & Ulmaceae & 2 & 3 & Aquifoliaceae & 1 & 1 \\
\hline 18 & Myrsinaceae & 2 & 3 & Araliaceae & 1 & 1 \\
\hline 19 & Sterculiaceae & 1 & 3 & Asteraceae & 1 & 1 \\
\hline 20 & Sapindaceae & 2 & 2 & Berberidaceae & 1 & 1 \\
\hline 21 & Daphniphyllaceae & 1 & 2 & Betulaceae & 1 & 1 \\
\hline 22 & Boraginaceae & 1 & 2 & Caprifoliaceae & 1 & 1 \\
\hline 23 & Myrtaceae & 2 & 2 & Corylaceae & 1 & 1 \\
\hline 24 & Aquifoliaceae & 1 & 2 & Daphniphyllaceae & 1 & 1 \\
\hline 25 & Fabaceae & 2 & 2 & Elaeagnaceae & 1 & 1 \\
\hline 26 & Juglandaceae & 1 & 1 & Erythroxylaceae & 1 & 1 \\
\hline 27 & Pittosporaceae & 1 & 1 & Juglandaceae & 1 & 1 \\
\hline 28 & Myricaceae & 1 & 1 & Meliaceae & 1 & 1 \\
\hline 29 & Meliaceae & 1 & 1 & Menispermaceae & 1 & 1 \\
\hline 30 & Asteraceae & 1 & 1 & Myrsinaceae & 1 & 1 \\
\hline 31 & Berberidaceae & 1 & 1 & Myrtaceae & 1 & 1 \\
\hline 32 & Simaroubaceae & 1 & 1 & Olacaceae & 1 & 1 \\
\hline 33 & Erythroxylaceae & 1 & 1 & Oleaceae & 1 & 1 \\
\hline 34 & Salicaceae & 1 & 1 & Polygalaceae & 1 & 1 \\
\hline 35 & Cannaceae & 1 & 1 & Rubiaceae & 1 & 1 \\
\hline 36 & Combretaceae & 1 & 1 & Rutaceae & 1 & 1 \\
\hline 37 & Betulaceae & 1 & 1 & Symplocaceae & 1 & 1 \\
\hline 38 & Moraceae & 1 & 1 & Ulmaceae & 1 & 1 \\
\hline 39 & Thymeliaceae & 1 & 1 & Urticaceae & 1 & 1 \\
\hline 40 & Tiliaceae & 1 & 1 & Verbenaceae & 1 & 1 \\
\hline 41 & Caprifoliaceae & 1 & 1 & & & \\
\hline 42 & Loganiaceae & 1 & 1 & & & \\
\hline 43 & Cappaceae & 1 & 1 & & & \\
\hline 44 & Sabiaceae & 1 & 1 & & & \\
\hline 45 & Urticaceae & 1 & 1 & & & \\
\hline 46 & Clusiaceae & 1 & 1 & & & \\
\hline 47 & Cornaceae & 1 & 1 & & & \\
\hline 48 & Caesalpiniaceae & 1 & 1 & & & \\
\hline
\end{tabular}

APPLIED ECOLOGY AND ENVIRONMENTAL RESEARCH 10(4): 417-436. http://www.ecology.uni-corvinus.hu • ISSN 15891623 (Print) • ISSN 17850037 (Online)

(c) 2012, ALÖKI Kft., Budapest, Hungary 


\section{Discussion}

The findings of present study revealed that both the forests inhabit climax vegetation and are best representative of subtropical humid forests of Meghalaya. During the investigation, 133 and 81 species were recorded from 0.5 ha area of Mairang and Mawphlang sacred forests, respectively. High species richness in former case may be due to formation of gaps due to felling of few mature trees, which had facilitated introduction of more species from neighboring forests. Mishra et al. (2003) have reported that mild disturbance supports species richness and have recorded high species richness in mildly/moderately disturbed stand of Swer sacred grove in Meghalaya. A similar result was also noticed by Upadhaya et al. (2003) and they have recorded 123 woody species from 1 ha area ( 0.5 ha each of Ialong and Raliang sacred groves in Jaintia hills of Meghalaya). High species richness in Mairang sacred forest showed that mild disturbance is linked with species turnover, colonization and high species richness (Whittaker, 1975; Connell, 1979). Mairang sacred forest had high species richness per unit area, which is due to presence of synuisae in the forest (Richards, 1996). Predominance of contagious distribution indicates interaction of abiotic and biotic factors acting together as population and it was more conspicuous in case of Mairang sacred forest. Insufficient mode of seed dispersal had resulted in clumping (Richards, 1996). Although clumping is the characteristic feature of natural forests (Armesto et al., 1986). Jamir (2000) has also reported a similar result in sacred forests of Meghalaya.

Change in edapho-climatic conditions due to variation in the altitude has altered species composition in two similar kinds of forests. The result showed that change in species composition is highly linked with variation in altitude, as both the forests are highly dissimilar (dissimilarity index 73\%) in terms of species composition. The present finding is in conformity with the work of Liberman et al. (1996) and Kadavul \& Parthasarathy (1999). The change in the position of dominant and codominant species and families in these two forests is also associated with variation in altitude. Despite high family richness in Mairang sacred forest, the number of monospecific families were low. This could be attributed to elimination of some families, which are very sensitive to low level of disturbance. Moreover, there was chance of inclusion of more species in the families with increased dominance. These sacred forests had a number of endemic and rare plants. Haridasan \& Rao (1985-87) have also pointed out that sacred forests of Meghalaya harbor a large number of such species, which are confined to sacred forests only.

Wide range girth-distribution in two forests indicates stability and complexity of community. Better recruitment of seedlings and predominance of individuals in lower girth classes (adults) showed high regeneration efficacy at forest stand level (Mishra et al., 2003; Laloo et al., 2006). Conversion of seedlings into saplings follows a similar pattern in two forests. Low conversion of saplings into trees in Mairang sacred forests could be due to presence of high canopy tree species. Gaps also facilitated expansion of crown of trees, and subsequently suppression of growth and survival of saplings growing beneath these trees (Mishra et al., 2003). Population structure at forest stand level indicates that these forests harbor a growing population (Mishra, 2004). Girth-distribution follows reverse J shaped curve, which suggests that both the forests are climax and stable (Mishra et al., 2005a).

The dominance-distribution pattern at the levels of species and family justifies mature, stable and complex nature of vegetation. High species content and more even distribution 
of IVI among the species in Mairang sacred forest depict high degree of stability and complexity of community (Mishra et al., 2004; Mishra et al, 2005a). It has been argued that the ecosystem with high species diversity is more stable and resilient to environmental disturbances than those having low species, diversity (Hurd et al., 1971; McNaughton, 1977, 1985; Tilman, 1988; Frank \& McNaughton, 1991; Tilman \& Downing, 1994).

\section{Conclusion}

From the present study it can be concluded that altitudinal variation leads to change in species composition and taxonomic position even in similar kind of forest. This could be due to altered edapho-climatic conditions of the area. Low level of disturbance in terms of felling of few trees can favour natural regeneration of woody species, it involves increased percent conversion of seedlings to saplings, and saplings to trees. Form earlier studies it is evident that majority of sacred forests are facing different degrees of disturbance, few forests $(\mathrm{ca} .10 \%)$ are still intact. In view of this, it is recommended that such kind of studies in addition to regeneration behaviour of dominant and important species need much attention of ecologists to find out appropriate strategy for in situ conservation of genetic resources on sustained basis. Strengthening researches and pooling data generated through extensive studies could be a tool for rehabilitation of degraded sacred forests, by planting suitable species.

Acknowledgements. The authors are thankful to the Department of Botany, North - Eastern Hill University, Shillong for extending necessary facilities to conduct this study. The Department of Science and Technology (DST), New Delhi is gratefully acknowledged for financial assistance to Dr. B.P. Mishra, in form of the Scheme for Young Scientists. 
Mishra - Jeeva: Plant diversity and community attributes of woody plants in two climax subtropical humid forests of Meghalaya $-428-$

Appendix 1. Community attributes of woody plant species in the two sacred forests of Meghalaya. Species rank was determined o the basis of IVI of a species

\begin{tabular}{|c|c|c|c|c|c|c|c|}
\hline \multirow[b]{2}{*}{ Plant species } & \multirow[b]{2}{*}{ Family } & \multicolumn{3}{|c|}{ Mairang sacred forest } & \multicolumn{3}{|c|}{ Mawphlang sacred forest } \\
\hline & & IVI & $\begin{array}{l}\text { Specie } \\
\text { s rank }\end{array}$ & $\begin{array}{l}\text { Whitford } \\
\text { index }\end{array}$ & IVI & $\begin{array}{c}\text { Species } \\
\text { rank }\end{array}$ & $\begin{array}{l}\text { Whitford } \\
\text { index }\end{array}$ \\
\hline $\begin{array}{l}\text { Acanthopanax aculeatum } \\
\text { Seem. }\end{array}$ & Araliaceae & 1.3 & 81 & 0.17 & - & - & - \\
\hline Actinidia callosa Lindl. & Actinidiaceae & - & - & - & 0.26 & 23 & 0.15 \\
\hline Aesculus assamica Griff. & Sapindaceae & 6.73 & 5 & 0.07 & - & - & - \\
\hline $\begin{array}{l}\text { Alangium chinense (Lour.) } \\
\text { Harms. }\end{array}$ & Cornaceae & 0.25 & 133 & 0.83 & - & - & - \\
\hline Alnus nepalensis D. Don. & Betulaceae & - & - & - & 4.07 & 10 & 0.21 \\
\hline $\begin{array}{l}\text { Alphonsea ventricosa Hk.f. \& } \\
\text { Thunb. }\end{array}$ & Annonaceae & 2.89 & 30 & 0.16 & - & - & - \\
\hline $\begin{array}{l}\text { Anomospermum excelsum } \\
\text { Dalz. }\end{array}$ & Euphorbiaceae & - & - & - & 0.8 & 45 & 0.09 \\
\hline Antidesma khasianum Hk. f. & Euphorbiaceae & - & - & - & 3.47 & 62 & 0.05 \\
\hline $\begin{array}{l}\text { Antidesma diandrum (Roxb.) } \\
\text { Roth. }\end{array}$ & Euphorbiaceae & 1.63 & 59 & 0.17 & - & - & - \\
\hline Antidesma roxburghii Wall. & Euphorbiaceae & - & - & - & 0.32 & 43 & 0.1 \\
\hline $\begin{array}{l}\text { Aporusa dioica (Roxb.) Muell.- } \\
\text { Arg. }\end{array}$ & Euphorbiaceae & - & - & - & 4.17 & 9 & 0.22 \\
\hline Aporusa roxburghii Baill. & Euphorbiaceae & 5.75 & 11 & 0.14 & - & - & - \\
\hline Aralia armata (G.Don) Seem. & Araliaceae & 1.23 & 85 & 0.17 & - & - & - \\
\hline Ardisia nerifolia DC. & Myrsinaceae & 1.01 & 103 & 0.38 & - & - & - \\
\hline Ardisia undulata $\mathrm{Cl}$. & Myrsinaceae & 0.6 & 124 & 1 & 0.24 & 51 & 0.08 \\
\hline $\begin{array}{l}\text { Baliospermum micranthum } \\
\text { Muell.-Arg. }\end{array}$ & Euphorbiaceae & - & - & - & 0.25 & 44 & 0.1 \\
\hline Bauhinia variegata Linn. & Caesalpiniaceae & 0.6 & 125 & 1 & - & - & - \\
\hline Beilshmiedia brandishii Hk.f. & Lauraceae & 5.56 & 12 & 0.12 & 1.95 & 56 & 0.06 \\
\hline Beilshmiedia fagifolia Nees. & Lauraceae & 1.51 & 66 & 0.22 & - & - & - \\
\hline $\begin{array}{l}\text { Beilshmiedia roxburghiana } \\
\text { Nees. }\end{array}$ & Lauraceae & 1.96 & 47 & 0.17 & - & - & - \\
\hline Berberis wallichiana DC. & Berberidaceae & - & - & - & 6.3 & 57 & 0.06 \\
\hline $\begin{array}{l}\text { Betula alnoides Buch.-Ham. ex } \\
\text { D.Don }\end{array}$ & Betulaceae & 1.26 & 84 & 0.5 & - & - & - \\
\hline Bidens spinosa Linn & Asteraceae & - & - & - & 0.27 & 58 & 0.06 \\
\hline Boehmeria platyphylla D.Don. & Urticaceae & 0.62 & 123 & 1 & - & - & - \\
\hline Boehmeria sidaefolia Wedd. & Urticaceae & - & - & - & 1.17 & 39 & 0.11 \\
\hline Brassiopsis aculeata Seem & Araliaceae & 1.39 & 79 & 0.22 & 0 & 0 & 0 \\
\hline Breynia retusa (Dennst.) Alst. & Euphorbiaceae & - & - & - & 0.59 & 46 & 0.09 \\
\hline Callicarpa arborea Roxb. & Verbenaceae & 2.24 & 37 & 0.16 & - & - & - \\
\hline $\begin{array}{l}\text { Callistemon citrinus (Curt) } \\
\text { Skeels }\end{array}$ & Myrtaceae & 1.44 & 74 & 0.22 & - & - & - \\
\hline Caloxylon leucocarpum Kurz. & Euphorbiaceae & - & - & - & 1.82 & 52 & 0.07 \\
\hline $\begin{array}{l}\text { Camellia caduca Cl. ex } \\
\text { Brandis. }\end{array}$ & Theaceae & 0.83 & 119 & 0.25 & 4.49 & 53 & 0.07 \\
\hline Camphora glandulifera Nees. & Lauraceae & - & - & - & 1.77 & 36 & 0.12 \\
\hline Capparis assamica Hk.f. \& Th. & Cappaceae & 0.99 & 106 & 0.38 & - & - & - \\
\hline $\begin{array}{l}\text { Carallia brachiata (Lour.) } \\
\text { Merr. }\end{array}$ & Cannaceae & 1.56 & 62 & 0.17 & - & - & - \\
\hline $\begin{array}{l}\text { Carpinus viminca Wall. ex } \\
\text { Lindl. }\end{array}$ & Corylaceae & - & - & - & 1.19 & 32 & 0.13 \\
\hline Castanopsis armata Spach. & Fagaceae & - & - & - & 1.77 & 47 & 0.09 \\
\hline Castanopsis kurzii (Hance). & Fagaceae & - & - & - & 4.67 & 37 & 0.12 \\
\hline Castanopsis sp. & Fagaceae & - & - & - & 3.77 & 40 & 0.11 \\
\hline $\begin{array}{l}\text { Celtis cinnamomea Lindl. ex } \\
\text { Planch. }\end{array}$ & Ulmaceae & 0.99 & 105 & 0.25 & - & - & - \\
\hline
\end{tabular}




\begin{tabular}{|c|c|c|c|c|c|c|c|}
\hline \multirow[b]{2}{*}{ Plant species } & \multirow[b]{2}{*}{ Family } & \multicolumn{3}{|c|}{ Mairang sacred forest } & \multicolumn{3}{|c|}{ Mawphlang sacred forest } \\
\hline & & IVI & $\begin{array}{l}\text { Specie } \\
\text { s rank }\end{array}$ & $\begin{array}{l}\text { Whitford } \\
\text { index }\end{array}$ & IVI & $\begin{array}{c}\text { Species } \\
\text { rank }\end{array}$ & $\begin{array}{l}\text { Whitford } \\
\text { index }\end{array}$ \\
\hline Celtis tetranda Roxb. & Ulmaceae & 3.22 & 25 & 0.16 & 0.69 & 12 & 0.19 \\
\hline $\begin{array}{l}\text { Cinnamomum glanduliferum } \\
\text { (Wall.) Meissn. }\end{array}$ & Lauraceae & 0.58 & 128 & 0.5 & $\begin{array}{c}11.0 \\
3\end{array}$ & 16 & 0.17 \\
\hline $\begin{array}{l}\text { Cinnamoтит pauciflorum } \\
\text { Nees }\end{array}$ & Lauraceae & 3.12 & 28 & 0.22 & 3.99 & 48 & 0.09 \\
\hline Сіппатотит sp. & Lauraceae & - & - & - & 1.58 & 54 & 0.07 \\
\hline Cissampelos pareira Linn. & Menispermaceae & - & - & - & 1.47 & 41 & 0.11 \\
\hline Citrus medica Linn. & Rutaceae & $\begin{array}{c}14.3 \\
4\end{array}$ & 1 & 0.04 & - & - & - \\
\hline Cleidion javanicum Bl. & Euphorbiaceae & 5.82 & 10 & 0.13 & 2.67 & 33 & 0.13 \\
\hline $\begin{array}{l}\text { Clerodendrum infortunatum } \\
\text { auct. non Linn. }\end{array}$ & Verbenaceae & 0.6 & 126 & 1 & - & - & - \\
\hline $\begin{array}{l}\text { Cleyera grandiflora Hk.f. \& } \\
\text { Th. ex Dyer }\end{array}$ & Theaceae & - & - & - & 1.64 & 59 & 0.06 \\
\hline Coffea khasiana Hk.f. & Rubiaceae & 1.93 & 48 & 0.39 & - & - & - \\
\hline Combretum acuminatum Roxb. & Combretaceae & 1.48 & 67 & 0.22 & - & - & - \\
\hline Cordia fragrantissima Kurz. & Boraginaceae & 2.17 & 40 & 0.18 & - & - & - \\
\hline Cordia grandis Roxb. & Boraginaceae & 1.55 & 63 & 0.22 & - & - & - \\
\hline Corylopsis himalayans Griff. & Hamamelidaceae & - & - & - & 0.33 & 20 & 0.16 \\
\hline Croton caudatus Geisel. & Euphorbiaceae & 0.85 & 118 & 0.25 & - & - & - \\
\hline Cryptocarya amygdalina Nees. & Lauraceae & 8.68 & 2 & 0.08 & - & - & - \\
\hline $\begin{array}{l}\text { Cryptocarya andersonii King } \\
\text { ex Hk. f. }\end{array}$ & Lauraceae & 3.96 & 22 & 0.13 & 5.45 & 71 & 0.03 \\
\hline Cryptocarya sp. & Lauraceae & - & - & - & 3.78 & 67 & 0.04 \\
\hline Cyclostemon assamicus Hk.f. & Euphorbiaceae & 4.13 & 20 & 0.16 & - & - & - \\
\hline Daphne cannabina Wall. & Thymeliaceae & 1.15 & 93 & 0.5 & - & - & - \\
\hline $\begin{array}{l}\text { Daphniphyllum himalayense } \\
\text { (Benth.) Muell.-Arg. }\end{array}$ & Daphniphyllaceae & 1.86 & 52 & 0.22 & 0.59 & 76 & 0.01 \\
\hline Daphniphyllum sp. & Daphniphyllaceae & 3.53 & 23 & 0.14 & - & - & - \\
\hline $\begin{array}{l}\text { Dysoxylum binectariferum } \\
\text { Hk.f. \& Bedd. }\end{array}$ & Meliaceae & 3.51 & 24 & 0.24 & 1.1 & 63 & 0.05 \\
\hline $\begin{array}{l}\text { Echinocarpus dasycarpus } \\
\text { Benth. }\end{array}$ & Elaeocarpaceae & 4.18 & 19 & 0.13 & 0.59 & 60 & 0.06 \\
\hline Echinocarpus murex Benth. & Elaeocarpaceae & 6.39 & 7 & 0.08 & - & - & - \\
\hline Elaeagnus latifolia Linn. & Elaeagnaceae & - & - & - & 1.07 & 34 & 0.13 \\
\hline $\begin{array}{l}\text { Elaeocarpus acuminatus Wall } \\
\text { ex Mast. }\end{array}$ & Elaeocarpaceae & 3.13 & 27 & 0.11 & - & - & - \\
\hline Elaeocarpus floribundus B1. & Elaeocarpaceae & 0.94 & 110 & 0.25 & - & - & - \\
\hline Elaeocarpus lancifolius Roxb. & Elaeocarpaceae & 2.26 & 36 & 0.16 & - & - & - \\
\hline Elaeocarpus sikkimensis Mast. & Elaeocarpaceae & - & - & - & 9.21 & 29 & 0.14 \\
\hline Elsholtzia blanda Benth. & Lamiaceae & - & - & - & 2.08 & 24 & 0.15 \\
\hline Embelia ribes Burm. f. & Myrsinaceae & 0.87 & 117 & 1.5 & - & - & - \\
\hline $\begin{array}{l}\text { Engelhardtia spicata Leschn ex } \\
\text { Bl. }\end{array}$ & Juglandaceae & 4.81 & 15 & 1 & 6.06 & 17 & 0.17 \\
\hline Eriobotrya dubia Decne. & Rosaceae & 1.45 & 72 & 0.38 & 1.14 & 30 & 0.14 \\
\hline Erythrina stricta Roxb. & Fabaceae & 1.01 & 104 & 0.38 & - & - & - \\
\hline $\begin{array}{l}\text { Erythroxylum kunthianum } \\
\text { Wall. ex. Kurz. }\end{array}$ & Erythroxylaceae & 1.65 & 58 & 0.22 & $\begin{array}{c}12.2 \\
7\end{array}$ & 6 & 0.23 \\
\hline Eugenia lanceolaria Roxb. & Myrtaceae & - & - & - & 0.99 & 18 & 0.17 \\
\hline Eupatorium odoratum Linn. & Asteraceae & 1.3 & 83 & 0.63 & - & - & - \\
\hline Eurya acuminata DC. & Theaceae & 3.05 & 29 & 0.18 & 16.3 & 74 & 0.02 \\
\hline Eurya japonica Thunb. & Theaceae & 1.82 & 53 & 0.16 & $\begin{array}{c}12.8 \\
5\end{array}$ & 77 & 0.01 \\
\hline $\begin{array}{l}\text { Exbucklandia populnea (R. Br. } \\
\text { ex Griff) R. W. Br. }\end{array}$ & Hamamelidaceae & - & - & - & 1.27 & 64 & 0.05 \\
\hline Fagraea ceilanica Thunb. & Loganiaceae & 1.03 & 98 & 0.38 & - & - & - \\
\hline Ficus hispida Linn. f. & Moraceae & 1.44 & 73 & 0.17 & - & - & - \\
\hline Ficus silhetensis Miq. & Moraceae & - & - & - & 0.56 & 19 & 0.17 \\
\hline Ficus sp. & Moraceae & - & - & - & 8.91 & 11 & 0.2 \\
\hline
\end{tabular}




\begin{tabular}{|c|c|c|c|c|c|c|c|}
\hline \multirow[b]{2}{*}{ Plant species } & \multirow[b]{2}{*}{ Family } & \multicolumn{3}{|c|}{ Mairang sacred forest } & \multicolumn{3}{|c|}{ Mawphlang sacred forest } \\
\hline & & IVI & $\begin{array}{l}\text { Specie } \\
\text { s rank }\end{array}$ & $\begin{array}{l}\text { Whitford } \\
\text { index }\end{array}$ & IVI & $\begin{array}{c}\text { Species } \\
\text { rank }\end{array}$ & $\begin{array}{l}\text { Whitford } \\
\text { index }\end{array}$ \\
\hline $\begin{array}{l}\text { Fissistigma wallichii (Hk.f. \& } \\
\text { Th.) Merr. }\end{array}$ & Annonaceae & 7.19 & 4 & 0.16 & - & - & - \\
\hline Garcinia cowa Roxb. ex DC. & Clusiaceae & 0.83 & 120 & 0.25 & 0.99 & 13 & 0.19 \\
\hline $\begin{array}{l}\text { Garcinia lancifolia (G. Don) } \\
\text { Roxb. }\end{array}$ & Clusiaceae & - & - & - & 1.25 & 25 & 0.15 \\
\hline Gaultheria ovalifolia Wall. & Ericaceae & - & - & - & 0.53 & 21 & 0.16 \\
\hline Glochidion assamicum Hk.f. & Euphorbiaceae & 1.41 & 75 & 0.13 & 4.61 & 7 & 0.23 \\
\hline Glochidion khasicum Hk.f. & Euphorbiaceae & 0.9 & 115 & 0.25 & 0.71 & 68 & 0.04 \\
\hline Grewia multiflora Juss. & Tiliaceae & 1.35 & 80 & 0.17 & - & - & - \\
\hline Helicia excelsa $\mathrm{Bl}$. & Proteaceae & - & - & - & 2.06 & 49 & 0.09 \\
\hline Helicia nilagirica Bedd. & Proteaceae & - & - & - & 4.28 & 26 & 0.15 \\
\hline Ilex embelioides Hk.f. & Aquifoliaceae & 1.15 & 94 & 0.5 & - & - & - \\
\hline Ilex khasiana Purk. & Aquifoliaceae & 0.96 & 109 & 0.38 & 3.34 & 2 & 0.29 \\
\hline Ixora acuminata Roxb. & Rubiaceae & 0.6 & 127 & 1 & - & - & - \\
\hline Leptodermis griffithii Hk.f. & Rubiaceae & 1.03 & 99 & 0.38 & - & - & - \\
\hline $\begin{array}{l}\text { Ligustrum indicum (Lour) } \\
\text { Merr. }\end{array}$ & Oleaceae & 1.48 & 68 & 0.22 & - & - & - \\
\hline $\begin{array}{l}\text { Ligustrum robustum (Roxb.) } \\
\text { Bl. }\end{array}$ & Oleaceae & 0.57 & 129 & 1 & - & - & - \\
\hline $\begin{array}{l}\text { Lindera caudata (Nees) Hook. } \\
\text { f. }\end{array}$ & Lauraceae & - & - & - & 1.4 & 42 & 0.11 \\
\hline Lindera latifolia Hk.f. & Lauraceae & 0.97 & 107 & 0.25 & - & - & - \\
\hline $\begin{array}{l}\text { Lindera pulcherrima (Nees) } \\
\text { Benth. }\end{array}$ & Lauraceae & 4.11 & 21 & 0.28 & - & - & - \\
\hline Litsea citrata $\mathrm{B} 1$. & Lauraceae & 1.78 & 54 & 0.13 & - & - & - \\
\hline $\begin{array}{l}\text { Litsea salicifolia (Roxb. ex } \\
\text { Nees.) Hk.f. }\end{array}$ & Lauraceae & 1.08 & 95 & 0.38 & - & - & - \\
\hline $\begin{array}{l}\text { Machilus bombycina King ex } \\
\text { Hk. f. }\end{array}$ & Lauraceae & - & - & - & 0.6 & 72 & 0.03 \\
\hline $\begin{array}{l}\text { Macropanax undulatus (wall. } \\
\text { ex G.Don) Seem. }\end{array}$ & Araliaceae & 6.37 & 8 & 0.08 & - & - & - \\
\hline Magnolia excelsa Wall. & Magnoliaceae & - & - & - & 0.86 & 50 & 0.09 \\
\hline Magnolia insignis (Wall.) Bl. & Magnoliaceae & - & - & - & 1.83 & 55 & 0.07 \\
\hline $\begin{array}{l}\text { Mahonia pycnophylla (Fedde) } \\
\text { Takeda }\end{array}$ & Berberidaceae & 2.21 & 39 & 0.28 & - & - & - \\
\hline $\begin{array}{l}\text { Meliosma wallichii Planch. ex } \\
\text { Hk.f. }\end{array}$ & Sabiaceae & 0.62 & 122 & 0.5 & - & - & - \\
\hline Melodinus khasianus Hook. f. & Apocynaceae & - & - & - & 3.24 & 31 & 0.14 \\
\hline Michelia champaca Linn. & Magnoliaceae & 1.52 & 64 & 0.17 & - & - & - \\
\hline Michelia lanuginosa Wall & Magnoliaceae & 0.92 & 112 & 0.25 & - & - & - \\
\hline $\begin{array}{l}\text { Michelia oblonga Wall. ex } \\
\text { Hk.f. }\end{array}$ & Magnoliaceae & 1.01 & 101 & 0.25 & - & - & - \\
\hline Michelia punduana Hk.f. & Magnoliaceae & 2.8 & 31 & 0.16 & - & - & - \\
\hline $\begin{array}{l}\text { Micromelum pubescens (non } \\
\text { Bl.) }\end{array}$ & Rutaceae & 1.76 & 55 & 0.22 & - & - & - \\
\hline $\begin{array}{l}\text { Millettia pulchra (Benth.) } \\
\text { Kurz. }\end{array}$ & Fabaceae & 1.01 & 102 & 0.25 & - & - & - \\
\hline Mussaenda roxburghii Hk.f. & Rubiaceae & 1.22 & 87 & 0.5 & - & - & - \\
\hline $\begin{array}{l}\text { Myrica esculenta Buch-Ham. } \\
\text { ex D.Don. }\end{array}$ & Myricaceae & - & - & - & 2.12 & 65 & 0.05 \\
\hline Myrica nagi Hk.f & Myricaceae & 1.6 & 61 & 0.22 & 1.11 & 69 & 0.04 \\
\hline Nauclea griffithii Hav. & Rubiaceae & 1.22 & 86 & 0.38 & - & - & - \\
\hline Neillia thyrsiflora D.Don. & Rosaceae & 0.4 & 132 & 0.5 & - & - & - \\
\hline $\begin{array}{l}\text { Neolitsea cassia (Linn.) } \\
\text { Kosterm. }\end{array}$ & Lauraceae & - & - & - & 11.6 & 35 & 0.13 \\
\hline Olax acuminata Benth. & Olacaceae & - & - & - & 0.75 & 3 & 0.28 \\
\hline Olea dentata Wall ex DC. & Oleaceae & 2.21 & 38 & 0.16 & - & - & - \\
\hline Olea dioica Roxb. & Oleaceae & 0.92 & 113 & 0.25 & - & - & - \\
\hline Olea salicifolia Wall. ex. Cl. & Oleaceae & - & - & - & 3.92 & 5 & 0.25 \\
\hline
\end{tabular}




\begin{tabular}{|c|c|c|c|c|c|c|c|}
\hline \multirow[b]{2}{*}{ Plant species } & \multirow[b]{2}{*}{ Family } & \multicolumn{3}{|c|}{ Mairang sacred forest } & \multicolumn{3}{|c|}{ Mawphlang sacred forest } \\
\hline & & IVI & $\begin{array}{l}\text { Specie } \\
\text { s rank }\end{array}$ & $\begin{array}{c}\text { Whitford } \\
\text { index }\end{array}$ & IVI & $\begin{array}{c}\text { Species } \\
\text { rank }\end{array}$ & $\begin{array}{c}\text { Whitford } \\
\text { index }\end{array}$ \\
\hline Ostodes paniculata $\mathrm{Bl}$. & Euphorbiaceae & 5.51 & 13 & 0.16 & - & - & - \\
\hline Panax armatus G. Don & Araliaceae & - & - & - & 1.1 & 14 & 0.19 \\
\hline $\begin{array}{l}\text { Persea bombycina (King ex } \\
\text { Hk.f.) Kosterm. }\end{array}$ & Lauraceae & 1.9 & 51 & 0.13 & - & - & - \\
\hline $\begin{array}{l}\text { Persea duthiei (King ex Hk.f.) } \\
\text { Kosterm. }\end{array}$ & Lauraceae & 2.1 & 44 & 0.16 & - & - & - \\
\hline Persea gamblei (King ex Hk.f.) & Lauraceae & 2.12 & 43 & 0.19 & - & - & - \\
\hline Kosterm. & & & & & & & \\
\hline Persea Khasyana Missn. & Lauraceae & 0.46 & 131 & 0.5 & - & - & - \\
\hline Persea kingii (Hk.f.) Kosterm. & Lauraceae & 1.15 & 90 & 0.25 & - & - & - \\
\hline Phoebe attenuata (Nees) Nees. & Lauraceae & 8.43 & 3 & 0.17 & - & - & - \\
\hline Phyllanthus retusus Dennst. & Euphorbiaceae & 1.17 & 89 & 0.5 & 1.47 & 27 & 0.15 \\
\hline Picrasma javanica $\mathrm{Bl}$. & Simaroubaceae & 2.12 & 42 & 0.16 & - & - & - \\
\hline Pittosporum glabratum Lindl. & Pittosporaceae & 4.32 & 18 & 0.28 & - & - & - \\
\hline $\begin{array}{l}\text { Plectranthus striatus Benth. in } \\
\text { Wall. }\end{array}$ & Lamiaceae & - & - & - & 1.5 & 1 & 0.31 \\
\hline Pogostemon strigosus Benth. & Lamiaceae & - & - & - & 1.55 & 4 & 0.27 \\
\hline $\begin{array}{l}\text { Polyalthia jenkinsii Benth. \& } \\
\text { Hk.f. }\end{array}$ & Annonaceae & 1.91 & 50 & 0.17 & - & - & - \\
\hline $\begin{array}{l}\text { Polygala arillata Buch.-Ham in } \\
\text { D. Don }\end{array}$ & Polygalaceae & - & - & - & 2.4 & 22 & 0.16 \\
\hline $\begin{array}{l}\text { Premna racemosa } \text { Schauer in } \\
\text { DC. }\end{array}$ & Verbenaceae & - & - & - & 0.89 & 8 & 0.23 \\
\hline $\begin{array}{l}\text { Prunus cerasoides D. Don. } \\
\text { Prodr. }\end{array}$ & Rosaceae & - & - & - & 1.49 & 38 & 0.12 \\
\hline $\begin{array}{l}\text { Prunus nepaulensis (Ser.) } \\
\text { Steud. }\end{array}$ & Rosaceae & 1.15 & 92 & 0.38 & - & - & - \\
\hline Psychotria symplocifolia Kurz. & Rubiaceae & 1.19 & 88 & 0.5 & 5.42 & 78 & 0.01 \\
\hline Pyrus pashia D.Don. & Rosaceae & 0.67 & 121 & 1 & - & - & - \\
\hline $\begin{array}{l}\text { Quercus dealbata Hk. f. \& Th. } \\
\text { ex Miq }\end{array}$ & Fagaceae & - & - & - & 4.61 & 73 & 0.03 \\
\hline Quercus glauca Thunb. & Fagaceae & 1.98 & 46 & 0.28 & 7.75 & 79 & 0.01 \\
\hline $\begin{array}{l}\text { Quercus griffithii Hk.f. \& Th. } \\
\text { ex DC. Prodr. }\end{array}$ & Fagaceae & 4.76 & 16 & 0.15 & $\begin{array}{c}14.5 \\
5\end{array}$ & 70 & 0.04 \\
\hline Quercus kamroopii D. Don. & Fagaceae & - & - & - & 6.89 & 66 & 0.05 \\
\hline Quercus semiserrata Roxb. & Fagaceae & 5.39 & 14 & 0.08 & - & - & - \\
\hline Randia longiflora Lamk. & Rubiaceae & 1.41 & 76 & 0.22 & - & - & - \\
\hline Rhododendron arboreum $\mathrm{Sm}$. & Ericaceae & - & - & - & $\begin{array}{c}39.6 \\
5\end{array}$ & 80 & 0.01 \\
\hline Rhus acuminata DC. & Anacardiaceae & 2.03 & 45 & 0.17 & - & - & - \\
\hline Rhus insignis Hk.f. & Anacardiaceae & 1.69 & 56 & 0.22 & - & - & - \\
\hline Rhus javanica Linn. & Anacardiaceae & 4.34 & 17 & 0.14 & - & - & - \\
\hline Salix psilostigma Anders. & Salicaceae & 1.4 & 78 & 0.5 & - & - & - \\
\hline $\begin{array}{l}\text { Sapindus attenuatus Wall. Ex } \\
\text { Hiern.Rark DC. }\end{array}$ & Sapindaceae & 0.97 & 108 & 1 & - & - & - \\
\hline Sapium baccatum Roxb. & Euphorbiaceae & 5.97 & 9 & 0.07 & 0.69 & 15 & 0.18 \\
\hline $\begin{array}{l}\text { Sapium eugeniaefolium Ham. } \\
\text { ex. Hk.f. }\end{array}$ & Euphorbiaceae & 1.15 & 91 & 0.25 & - & - & - \\
\hline Sarcococca pruniformis Lindl. & Buxaceae & 1.08 & 96 & 0.38 & - & - & - \\
\hline $\begin{array}{l}\text { Sarcococca saligna (D.Don) } \\
\text { Muell-Arg. }\end{array}$ & Buxaceae & 1.46 & 71 & 0.25 & - & - & - \\
\hline Sarcococca sp. & Buxaceae & 1.41 & 77 & 0.22 & - & - & - \\
\hline $\begin{array}{l}\text { Schefflera hypoleuca (Kurz.) } \\
\text { Harms. }\end{array}$ & Araliaceae & 2.65 & 34 & 0.25 & - & - & - \\
\hline $\begin{array}{l}\text { Schefflera venulosa (W\&A) } \\
\text { Harms. }\end{array}$ & Araliaceae & 1.46 & 70 & 0.22 & - & - & - \\
\hline $\begin{array}{l}\text { Schefflera wallichiana (W \& } \\
\text { A) Harms. }\end{array}$ & Araliaceae & 2.75 & 32 & 0.16 & - & - & - \\
\hline Schima khasiana Dyer. & Theaceae & 1.6 & 60 & 0.17 & - & - & - \\
\hline
\end{tabular}




\begin{tabular}{|c|c|c|c|c|c|c|c|}
\hline \multirow[b]{2}{*}{ Plant species } & \multirow[b]{2}{*}{ Family } & \multicolumn{3}{|c|}{ Mairang sacred forest } & \multicolumn{3}{|c|}{ Mawphlang sacred forest } \\
\hline & & IVI & $\begin{array}{l}\text { Specie } \\
\text { s rank }\end{array}$ & $\begin{array}{l}\text { Whitford } \\
\text { index }\end{array}$ & IVI & $\begin{array}{c}\text { Species } \\
\text { rank }\end{array}$ & $\begin{array}{l}\text { Whitford } \\
\text { index }\end{array}$ \\
\hline Schima wallichii (DC.) Korth. & Theaceae & 6.72 & 6 & 0.09 & 3.36 & 81 & 0.01 \\
\hline $\begin{array}{l}\text { Skimmia laureola (DC.) Sieb. } \\
\& \text { Zucc. }\end{array}$ & Rutaceae & 1.48 & 69 & 0.38 & - & - & - \\
\hline $\begin{array}{l}\text { Sterculia hamiltonii (O. Ktze.) } \\
\text { Adelb. }\end{array}$ & Sterculiaceae & 1.67 & 57 & 0.22 & - & - & - \\
\hline Sterculia roxburghii Wall. & Sterculiaceae & 0.9 & 116 & 0.25 & - & - & - \\
\hline Sterculia villosa Roxb. & Sterculiaceae & 0.51 & 130 & 0.5 & - & - & - \\
\hline Symplocos racemosa Roxb. & Symplocaceae & 1.06 & 97 & 0.38 & - & - & - \\
\hline $\begin{array}{l}\text { Symplocos crataegoides } \\
\text { D.Don. }\end{array}$ & Symplocaceae & 1.93 & 49 & 0.39 & - & - & - \\
\hline Symplocos spicata Roxb. & Symplocaceae & 2.66 & 33 & 0.16 & 7.8 & 75 & 0.02 \\
\hline Symplocos theaefolia D.Don. & Symplocaceae & 0.92 & 114 & 0.25 & - & - & - \\
\hline Syzygium balsameum (Wt.) & Myrtaceae & 1.3 & 82 & 0.17 & - & - & - \\
\hline $\begin{array}{l}\text { Wall ex AM. \& SM. Cowan. } \\
\text { Tapiria hirsuta Hk.f. }\end{array}$ & Anacardiaceae & 3.17 & 26 & 0.16 & - & - & - \\
\hline Trevesia palmata (Roxb.) Vis. & Araliaceae & 2.16 & 41 & 0.38 & - & - & - \\
\hline Vernonia vulkamerifolia DC. & Asteraceae & 0.94 & 111 & 0.25 & - & - & - \\
\hline Viburnum foetidum Wall. & Caprifoliaceae & 1.03 & 100 & 0.38 & 2.48 & 61 & 0.06 \\
\hline Vitex negundo Linn. & Verbenaceae & 1.51 & 65 & 0.17 & - & - & - \\
\hline Vitex vestita Roxb. & Verbenaceae & 2.4 & 35 & 0.22 & - & - & - \\
\hline Zanthoxylum khasianum Hk. f. & Rutaceae & - & - & - & 0.36 & 28 & 0.15 \\
\hline
\end{tabular}

Abbreviation: -, absent.

\section{REFERENCES}

[1] Andel van, T.R. (2001): Floristic composition and diversity of mixed primary and secondary forest in northwest Guyana. - Biodiversity and Conservation 10: 1645-1682.

[2] Armesto, J.J., Mitchell, J.D., Villogram, C. (1986): A comparison of spatial pattern of trees in tropical and temperate forests. - Biotropica 18: 1-11.

[3] Balakrishnan, N.P. (1981-1983): Flora of Jowai and Vicinity, Meghalaya, 2 Volumes. Botanical Survey of India, Howrah, India.

[4] Balakrishnan, N.P., Vasudeva, M.K. (1983): The dwindling plant species of Andman and Nicobar Islands. - In: An assessment of threatened plants of India (Jain, S.K., Rao, R.R. eds), Botanical Survey of India, Howrah, pp. 86-210.

[5] Behera, M.D., Kushwaha, S.P.S., Roy, P.S. (2002): High plant endemism in an Indian hotspot - eastern Himalaya. - Biodiversity and Conservation 11: 669-682.

[6] Cannon, C.H., Peart, D.R., Leighton, M. (1998): Tree species diversity in commercially logged Bornean rain forest. - Science 28: 1366-1368.

[7] Champion, H.G., Seth, S.K. (1968): A Revised Survey of the Forest Types of India. Government of India, New Delhi, India.

[8] Condit, R., Hubbell, S.P., Lafrankie, J.V., Sukumar, R., Manokaran, N., Foster, R.B., Ashton, P.S. (1996) Species-area and species-individual relationships for tropical trees: a comparison of three 50-ha plots. - Journal of Ecology 84: 549-562.

[9] Connell, J.H. (1978): Diversity in tropical rainforests and coral reefs. - Science 119: 13021309.

[10] Daniels, R.J.R. (1997): Taxonomic uncertainties and conservation assessment of the Western Ghats. - Current Science 73(2): 169-170.

[11] Daniels, R.J.R., Gadgil, M., Joshi, N.V. (1995): Impact of human extraction on tropical humid forests in the Western Ghats in Uttara Kannada, south India. - Journal of Applied Ecology 32: 866-874. 
[12] Daniels, R.J.R., Hegde, M., Joshi, N.V., Gadgil, M. (1991): Assigning conservation value a case study from India. - Conservation Biology 5: 464-475.

[13] Edwards, P.J., Cyrus, A. (1998): The value of biodiversity: where ecology and economics blend. - Biodiversity and Conservation 83: 239-246.

[14] Fashing, P.J., Gathua, J.M. (2004): Spatial variation in the structure and composition of an East African rain forest. - African Journal of Ecology 42(3): 189-197.

[15] Fashing, P.J., Forrestel, A., Scully, C., Cords, M. (2004): Long-term tree population dynamics and their implications for the conservation of the Kakamega Forest, Kenya. Biodiversity and Conservation 13(4): 753-771.

[16] Forest Survey of India (1997): The State of Forest Report. Ministry of Environment and Forests. - Dehra Dun, India.

[17] Frank, D.A., McNaughton, S.J. (1991): Stability increases with diversity in plant communities: empirical evidence from the 1988 yellow stone drought. - Oikos 62: 360362.

[18] Gadgil, M. (1996): Documenting diversity: An experiment. - Current Science 70(1): 36-44.

[19] Gadgil, M., Vartak, V.D. (1975): Sacred groves of India: A plea for continued conservation. - Journal of Bombay Natural History Society 72: 314-320.

[20] Gadgil, M., Vartak, V.D. (1976): Sacred groves of Western Ghats of India. - Economic Botany 30: 152-160.

[21] Gansser, A. (1964): Geology of the Himalayas. - Interscience, NewYork, United States of America.

[22] Gentry, A.H. (1992): Tropical forest biodiversity: distributional pattern and their conservational significance. - Oikos 63(1): 19-28.

[23] Groombridge, B. (ed.) (1992): Global biodiversity: status of the earth's living resources. Chapman and Hall, London.

[24] Grytnes, J.A. (2003): Species-richness patterns of vascular plants along seven altitudinal transects in Norway. - Ecography 26: 291-300.

[25] Haridasan, K., Rao, R.R. (1985-1987): Forest Flora of Meghalaya, 2 Volumes. - Bishen Singh Mahendra Pal Singh, Dehra Dun, India.

[26] Hurd, L.E., Mellinger, M.V., Wolf, L.L., McNaughton, S.J. (1971) Stability and diversity at three trophic levels in terrestrial systems. - Science 173: 1134-1136.

[27] Jamir, S.A. (2000): Studies on plant biodiversity, community structure and population behaviour of dominant tree species of some sacred groves of Jaintia hills, Meghalaya. $-\mathrm{Ph}$. D. Thesis, North, Eastern Hill University, Shillong, India.

[28] Jeeva, S., Anusuya, R. (2005): Ancient ecological heritage of Meghalaya. - Magnolia 3: 20-22.

[29] Jeeva, S., Mishra, B.P., Venugopal, N., Kharlukhi, L., Laloo, R.C. (2006a): Traditional knowledge and biodiversity conservation in the sacred groves of Meghalaya. - Indian Journal of Traditional Knowledge 5(4)

[30] Jeeva, S., Laloo, R.C., Mishra, B.P. (2006b): Traditional agricultural practices of Meghalaya. - Indian Journal of Traditional Knowledge 5(1): 7-18.

[31] Jeeva, S., Mishra B.P., Venugopal, N., Laloo, R.C. (2005) Sacred forests: traditional ecological heritage of Meghalaya. - Journal of Scott Research Forum 1(1): 93-97.

[32] Kadavul, K, Parthasarathy, N. (1999): Structure and composition of woody species in tropical semi-evergreen forest Kalrayan Hills, Eastern Ghats, India. Tropical Ecology 40: 247-260.

[33] Kanjilal, V.N., Kanjilal, P.C., Das, A., De, R.N., Bor, N.L. (1934-1940) Flora of Assam, 5 Volumes. - Government Press, Shillong, India.

[34] Kershaw, K.A. (1973): Quantitative and Dynamic Plant Ecology. - Edward Arnold, London, United Kingdom.

APPLIED ECOLOGY AND ENVIRONMENTAL RESEARCH 10(4): 417-436. http://www.ecology.uni-corvinus.hu • ISSN 15891623 (Print) • ISSN 17850037 (Online) (c) 2012, ALÖKI Kft., Budapest, Hungary 
[35] Kessler, M. (2000): Elevational gradients in species richness and endemism of selected plant groups in the central Bolivian Andes. - Plant Ecology 149: 181-193.

[36] Korner, C. (2000): Why are there global gradients in species richness? Mountains might hold the answer. - Trends in Ecology and Evolution 15: 513-514.

[37] Laloo, R.C., Kharlukhi, L., Jeeva, S., Mishra, B.P. (2006): Status of medicinal plants in the disturbed and the undisturbed sacred forests of Meghalya, northeast India: population structure and regeneration efficacy of some important species. - Current Science 90(2): 225-232.

[38] Lieberman, D., Lieberman, M., Peralta, R., Hartshorn, G.S. (1996): Tropical forest structure and composition on a large-scale altitudinal gradient in Costa Rica. - Journal of Ecology 84: 137-152.

[39] Margalef, R. (1958): Information theory in ecology. - General Systems 3: 36-71.

[40] McNaughton, S.J. (1977): Diversity and stability of ecological communities: a comment on the role of empiricism in ecology. - American Naturalist 111: 515-525.

[41] McNaughton, S.J. (1985): Ecology of a grazing system: the Serengeti. - Ecological Monographs 55: 259-294.

[42] McNeely, J.A. (1996): Assessing methods for setting conservation priorities. - Paper presented to OECD conference on biodiversity. Cairns, Australia.

[43] Menon, S., Bawa, K.S. (1997): Applications of Geographic Information Systems (GIS), remote-sensing, and a landscape ecology approach to biodiversity conservation in the Western Ghats. - Current Science 73(2): 134-145.

[44] Mishra, B.P., Tripathi, R.S., Tripathi, O.P., Pandey, H.N. (2003): Effect of disturbance on the regeneration of four dominant and economically important woody species in a broadleaved subtropical humid forest of Meghalaya, northeast India. - Current Science 84(11): 1449-1453.

[45] Mishra, B.P., Tripathi, O.P., Tripathi, R.S., Pandey, H.N. (2004): Effects of anthropogenic disturbance on plant diversity and community structure of a sacred grove in Meghalaya, northeast India. - Biodiversity and Conservation 13: 421-436.

[46] Mishra, B.P., Tripathi, O.P., Laloo, R.C. (2005a): Community characteristics of a climax subtropical humid forest of Meghalaya and population structure of ten important tree species. - Tropical Ecology 46(2).

[47] Mishra, B.P., Jeeva, S., Laloo, R.C. (2005b): Effect of fragmentation on plant diversity and community characters of the sacred groves of Meghalaya, northeast India. - In: National Conference on Current Trends of Research in Science and Technology, Organized by Gauhati University, Guwahati, Assam, India, Abstract No OP-L14, pp. 107.

[48] Mishra, B.P., Jeeva, S., Laloo, R.C. (2005c): Sacred groves of Meghalaya: A traditional ecological heritage for in situ conservation of plant diversity. - In: International symposium on Integrated Management of Fungal Diseases (IMF), Organized by Banaras Hindu University (BHU), Varanasi, India, pp. 81.

[49] Misra, R. (1968): Ecology Work Book. - Oxford and IBH Publishing Company, Calcutta, India.

[50] Mueller-Dombois, D., Ellenberg, H. (1974): Aims and Methods of Vegetation Ecology. John Wiley and Sons, New York, United States of America.

[51] Myers, N. (1988): Threatened biotas: 'hotspots' in tropical forests. - Environmentalist 8: 187-208.

[52] Myers, N., Mittermeier, R.A., Mittermeier, C.G., da Fonseca, G.A.B., Kents, J. (2000): Biodiversity hotspots for conservation priorities. - Nature 403: 853-858.

[53] Myking, T. (2002): Evaluating genetic resources of forest trees by means of life history traits - a Norwegian example Biodiversity and Conservation 11(9): 1681-1696. 
[54] Nagendra, H. (2001): Incorporating landscape transformation into local conservation prioritization: a case study in the Western Ghats, India. - Biodiversity and Conservation 10(3): 353-365.

[55] Nagendra, H., Gadgil, M. (1998): Linking regional and landscape scales for assessing biodiversity: A case study from Western Ghats. - Current Science 75(3): 264-271.

[56] Nagendra, H., Gadgil, M. (1999a): Satellite imagery as a tool for monitoring species diversity: An assessment. - Journal of Applied Ecology 36: 388-397.

[57] Nagendra, H., Gadgil, M. (1999b): Biodiversity assessment at multiple scales: Linking remotely sensed data with field information. - Proceedings of the National Academy of Sciences USA 96(16): 9154-9158.

[58] Nagendra, H., Utkarsh, G. (2003): Landscape Ecological Planning through a Multi-Scale Characterization of Pattern: Studies in the Western Ghats, South India. - Environmental Monitoring Assessment 87(3): 815-833.

[59] Nayar, M.P., Sastry., A.R.K. (eds) (1987): Red Data Book of Indian Plants, Volume I. Botanical Survey of India, Calcutta.

[60] Nayar, M.P., Sastry, A.R.K. (eds) (1988): Red Data Book of Indian Plants, Volume II. Botanical Survey of India, Calcutta.

[61] Nayar, M.P., Sastry, A.R.K. (eds) (1990): Red Data Book of Indian Plants, Volume III. Botanical Survey of India, Calcutta.

[62] Niering, W.A. (1987): Vegetation dynamics (succession and climax) in relation to plant community management. - Conservation Biology 1(4): 287-295.

[63] NRSA (1995): Report on area statistics of land use/land cover generated using remote sensing techniques, India. - Prepared by Land Use, Cartography and Map Printing Group National Remote Sensing Agency, Balanagar, Hyderabad, pp. 19-23.

[64] Odland, A., Birks, H.J.B. (1999): The altitudinal gradient of vascular plant species richness in Aurland, western Norway. - Ecography 22: 548-566.

[65] Ohlemuller, R., Wilson, J.B. (2000): Vascular plant species richness along latitudinal and altitudinal gradients: a contribution from New Zealand temperate rainforests. - Ecology Letters 3: 262-266.

[66] Oldfield, Lusty, S.C., MacKinven, A. (1998): The World list of Threatened Trees. - World Conservation Union Publications, Cambridge, United Kingdom.

[67] Phillips, O.L. (1997): The changing ecology of tropical forests. - Biodiversity and Conservation 6: 291-311.

[68] Pramod, P., Joshi, N.V., Ghate, U., Gadgil, M. (1997): On the hospitality of Western Ghats habitats for bird communities. - Current Science 73: 122-127.

[69] Rahbek, C. (1995): The elevational gradient of species richness, a uniform pattern? Eocgraphy 18: 200-205.

[70] Rennolls, K., Laumonier, Y. (2000): Species diversity structure analysis at two sites in the tropical rainforest of Sumatra. - Journal of Tropical Ecology 16: 253-270.

[71] Richards, P.W. (1996): The Tropical Rainforest, $2^{\text {nd }}$ edition. - Cambridge University Press, Cambridge.

[72] Rohde, K. (1992): Latitudinal gradients in species diversity, the search for the primary cause. - Oikos 65: 514-527.

[73] Sagar, R., Raghubanshi, A.S., Singh, J.S. (2003): Tree species composition, dispersion and diversity along a disturbance gradient in a dry tropical forest region of India. - Forest Ecology and Management 186: 61-71.

[74] Shannon, C.E., Weaver, W. (1949): The Mathematical Theory of Communication. University of Illinois Press, Urbana, Illinois, pp. 1-117.

[75] Simpson, E.H. (1949): Measurement of diversity. - Nature 163: 688.

[76] Singh, J.S. (2002): The biodiversity crisis: a multifaceted review. - Current Science 82: 638-647.

APPLIED ECOLOGY AND ENVIRONMENTAL RESEARCH 10(4): 417-436. http://www.ecology.uni-corvinus.hu • ISSN 15891623 (Print) • ISSN 17850037 (Online) (c) 2012, ALÖKI Kft., Budapest, Hungary 
[77] Srinivas, V., Parthasarathy, N. (2000): Comparative analysis of tree diversity and dispersion in the tropical lowland evergreen forest of Agumbe, central Western Ghats, India. - Tropical Biodiversity 7: 45-60.

[78] Takhtajan, A. (1969): Flowering plants: origin and dispersal. - Edinburgh: Oliver and Body.

[79] Tilman, D. (ed.) (1988): Plant Strategies and the Dynamics and Structure of Plant Communities. - Princeton University Press, Princeton.

[80] Tilman, D., Downing, J.A. (1994): Biodiversity and stability in grasslands. - Nature 367: 363-365.

[81] UNEP (1995): Global Biodiversity Assessment. - Cambridge University Press, Cambridge, United Kingdom.

[82] Upadhaya, K., Pandey, H.N., Law, P.S., Tripathi, R.S. (2003): Tree diversity in sacred groves of the Jaintia hills in Meghalaya, northeast India. - Biodiversity and Conservation 12: 583-597.

[83] WCMC (1992): Global Biodiversity: Status of the Earth's Living Resources. - Chapman and Hall, London.

[84] Whitford, P.B. (1948): Distribution of woodland plants in relation to succession and clonal growth. - Ecology 30: 199-208.

[85] Whitmore, T.C. (ed.) (1984): Tropical Rain Forests of the Far East, Second Edition. Oxford University Press, Oxford, United Kingdom.

[86] Whitmore, T.C. (1998): An introduction to tropical rain forests. - Oxford University Press, Oxford, New York, Tokyo.

[87] Whitmore, T.C., Sidiyasa, K. (1986): Comparison and structure of a lowland rain forest in Taraut, Northern Sulawesi. - Kew Bulletin 41: 747-756.

[88] Whittaker, R.H. (1975): Communities and Ecosystems. - MacMillan Publishing Company, New York.

[89] Wilson, J.B., Lee, W.G., Mark, A.F. (1990): Species diversity in relation to ultramafic substrate and to altitude in south-western New Zealand. - Vegetatio 86: 15-20. 